\author{
Marta Postula \\ Uniwersytet Warszawski \\ e-mail: mpostula@wz.uw.edu.pl
}

\title{
Jarosław Klepacki
}

Społeczna Akademia Nauk

e-mail: jaroslawklepacki@poczta.onet.pl

\section{REGUŁY DŁUGU PUBLICZNEGO \\ STABILIZATOREM FINANSÓW PUBLICZNYCH GRUPY WYSZEHRADZKIEJ}

\section{THE RULES OF PUBLIC DEBT AS A STABILIZER OF VISEGRAD GROUP PUBLIC FINANCES}

DOI: $10.15611 /$ pn.2018.532.28

JEL Classification: E62, H71, H72, H74, R51

Streszczenie: Reguły fiskalne w swojej istocie mają na celu zmniejszenie zachęt do nadmiernego zadłużania krajów poprzez stworzenie przejrzystych i jasno zdefiniowanych reguł w przepisach prawa. Ostatni kryzys podważył jednak ich skuteczność z powodu problemów $\mathrm{z}$ odpowiednim wdrożeniem, a następnie wyegzekwowaniem stworzonych zasad. W artykule przedstawiono wyniki badań na temat wpływu reguł fiskalnych, w szczególności reguł długu publicznego, w krajach Grupy Wyszehradzkiej na wskaźniki finansów publicznych, tzn. relacje długu i deficytu sektora finansów publicznych z PKB. Wyniki badań wskazały, że istnieje stosunkowo niewielki pozytywny efekt wprowadzenia reguł fiskalnych na spełnienie przez kraje je wykorzystujących kryteriów z Maastricht, za to widać ich pozytywny wpływ na kształtowanie się kosztów obsługi zadłużenia.

Słowa kluczowe: reguły fiskalne, dług publiczny, finanse publiczne, Grupa Wyszehradzka.

Summary: The fiscal rules are essentially aimed at reducing incentives for excessive indebtedness of countries by creating transparent and clearly defined rules in legal provisions. However, the last crisis undermined their effectiveness due to problems with proper implementation. The article presents the results of research on the impact of fiscal rules, in particular the rules of public debt, in the Visegrad Group countries on public finance indicators, i.e. debt and public sector deficit ratios with GDP. The results of the research indicated that there is a relatively small positive effect of the introduction of fiscal rules on the fulfillment of the Maastricht criteria by countries using them, but their positive impact on the formation of debt servicing costs can be seen.

Keywords: fiscal rules, public debt, public finances, Visegrad Group. 


\section{Wstęp}

Reguły fiskalne są narzędziem wpisującym się w charakterystykę przejrzystej polityki fiskalnej. Istotne znaczenie ma tu zwiększenie przewidywalności działań prowadzonych w obrębie sektora publicznego, ograniczające możliwość nieodpowiedzialnych zachowań polityków. Pośrednio stosowanie reguł może również wymusić przeprowadzenie niezbędnych reform systemowych. Ustalanie celów funkcjonowania reguł musi być spójne z ich konstrukcją, a zatem skalą oddziaływania. Reguły często tworzą podstawy polityki fiskalnej, jednocześnie wymagając wysokich standardów informacyjnych, aby skutecznie funkcjonować [Poterba 1994; Musgrave, Musgrave 1984]. Celem artykułu jest wskazanie, czy reguły długu publicznego stosowane we wszystkich krajach Grupy Wyszehradzkiej mają wpływ na konwergencję fiskalną, tj. spełnienie przez nie kryteriów z Maastricht.

Do weryfikacji empirycznej hipotez wywodzących się z przedstawionego problemu badawczego zostanie wykorzystana metodologia mieszana - zarówno wyniki badań jakościowych, jak i wyniki badań ilościowych. Badania jakościowe oparto na analizie opisowej, a badania ilościowe z kolei obejmować będą metodę systematyzacji informacji statystycznych, opartą na analizie źródłowych danych statystycznych, metodologię statystycznej zależności, w tym współczynnik korelacji liniowej Pearsona oraz analizę regresji.

\section{Reguły długu publicznego podstawowymi regułami stosowanymi w UE}

Krajowe reguły fiskalne powinny mieć na celu poprawę stabilności, przewidywalności i wiarygodności polityki fiskalnej, w tym w szczególności rozwiązanie kwestii narastającego poziomu deficytu budżetowego oraz długu publicznego, który może być spowodowany m.in. przez krótkowzroczność polityków, i zadanie to powinno być ich nadrzędnym, wspólnym problemem do rozwiązania. Zasady polityki fiskalnej przyświecające tworzeniu reguł fiskalnych można podzielić na kilka kategorii w zależności od podejścia do tego zagadnienia [MFW 1999].

Wybrane reguły fiskalne powinny pozwalać na realizację programu gospodarczego rządu przy z góry zaplanowanych ramach fiskalnych, zapewniających utrzymanie makroekonomicznej stabilności. W tym kontekście na pierwszy plan wysuwa się problem utrzymania $\mathrm{w}$ ryzach deficytu i długu publicznego. Wprowadzenie, a wcześniej opracowanie reguł fiskalnych jest procesem bardzo skomplikowanym i uzależnionym od struktury oraz sytuacji finansów publicznych w danym kraju [Postuła 2017, s. 103-112]. Pamiętać jednak należy, że z praktycznego punktu widzenia i przy uwzględnieniu specyfiki obecnego otoczenia zewnętrznego (wysoce zmiennego i mało przewidywalnego) tworzenie i inkorporowanie reguł fiskalnych odbywa się w oparciu o określone przewidywania i założenia uwzględniają przyjęty model 
i cel. Innymi słowy, jako racjonalne przyjąć należy, że dane reguły fiskalne znajdują zastosowanie i są efektywne tylko w dedykowanej do nich rzeczywistości społeczno-gospodarczej. Kalibracja i aktualizacja wydaje się zjawiskiem nieuniknionym i koniecznym.

W 2016 r. 22 państwa członkowskie UE na różnych poziomach stosowały reguły odnoszące się do długu publicznego [OECD 2016]. Na poziomie administracji centralnej regulacje odnoszące się do reguł długu publicznego mają charakter zrelatywizowany do PKB. Ostatni kryzys gospodarczy i wywołane nim skutki dla finansów publicznych poszczególnych krajów sprawiły, że bardzo wzrosło zainteresowanie regułami odnoszącymi się do poziomu zadłużenia, ponieważ jednym z głównych wymiarów prowadzonej polityki fiskalnej stało się w większości krajów jego ograniczenie.

Skuteczność reguł długu publicznego zależy od celów i determinacji ich twórców oraz od wielu cech konstrukcyjnych, w szczególności od sposobu monitorowania i egzekwowania. Poza tym funkcjonowaniu reguł długu publicznego mogą towarzyszyć skutki negatywne dla jakości wydatków publicznych oraz te same potencjalne ,pułapki”, co w przypadku reguł deficytu, zwłaszcza w odniesieniu do funkcji stabilizacyjnej finansów publicznych [Bova i in. 2014]. Podobnie jak inne reguły fiskalne, reguły długu publicznego powinny być stosowane w perspektywie średniookresowej i mieć charakter stabilizacyjny dla gospodarki oraz zmniejszać potencjalnie procykliczne działania rządu [Grauwe, Foresti 2015]. Istotnym elementem dla efektywności tego rodzaju reguł jest koordynacja polityki na wszystkich szczeblach administracji przy ustalaniu celów budżetowych tak, aby zrównoważyć możliwe efekty procykliczne wynikające z przepisów dłużnych stosowane na poziomie samorządowym. Antycykliczne zdefiniowanie reguł długu publicznego może być wzmocnione przez „klauzulę wyjścia” z ich stosowania za pomocą dochodów dyskrecjonalnych [Bova i in. 2015].

Reguły długu są stosowane z kilku powodów, po pierwsze znaczna część krajów członkowskich Unii Europejskiej ma kłopoty z utrzymaniem jego wartości referencyjnej (rys. 1).

W niektórych państwach UE dług publiczny był już na wysokim poziomie przed kryzysem 2008 r., a jego zaistnienie wprowadziło niebezpieczeństwo niewypłacalności kilku krajów (m.in.: Irlandii, Grecji, Portugalii).

Drugi z argumentów to fakt, że przy wysokim poziomie długu publicznego finanse publiczne stają się w dużej mierze podatne na niekorzystne wahania stóp procentowych oraz zaburzenia w cyklu koniunkturalnym. Zaburzenia takie co do zasady nie mają charakteru tylko jednokierunkowego. W przypadku stóp procentowych oznaczać to może zarówno gwałtowny spadek, jak i wzrost. Bezpośrednią reakcją banków centralnych na paniczną wyprzedaż na rynkach finansowych było nieoczekiwane cięcie stóp procentowych. Konsekwencją tego jest oczywiście intensywny spadek rentowności na rynku długu, co tylko pozornie z poziomu kosztów stabilizuje dług publiczny, zachęcając do dalszego zadłużania. Nagły i znaczny spadek ren- 


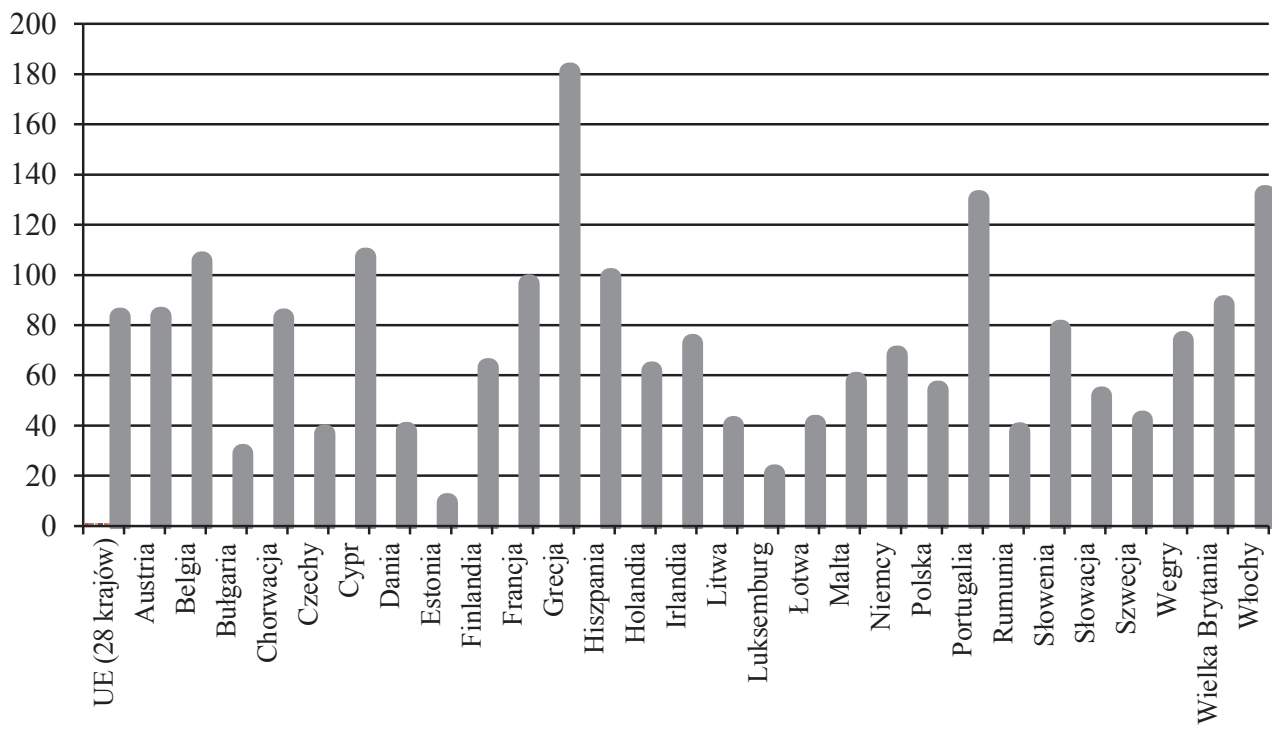

Rys. 1. Relacja długu publicznego do PKB w 2016 r. w UE

Źródło: opracowanie własne na podstawie danych Eurostatu.

towności papierów dłużnych oznacza destabilizację popytu ze strony inwestorów. Jednocześnie w sytuacji złego stanu finansów publicznych nawet niewielki wzrost stóp procentowych może, z jednej strony, spowodować odroczenie w czasie realizacji rozwojowych programów rządowych, natomiast z drugiej może się pojawić obawa o wystąpienie tzw. pułapki zadłużenia kraju [Alińska 2017]. Obydwa te zjawiska mogą spowodować, że zmniejszy się popyt instytucjonalnych inwestorów zainteresowanych zakupem skarbowych papierów wartościowych. Zmiany stóp procentowych mogą automatyczne zwiększać ryzyko wzrostu kosztów obsługi długu i tym samym „wypierać" inne prorozwojowe wydatki publiczne. Grecja, Irlandia i Portugalia, które zostały najciężej dotknięte przez europejski kryzys zadłużenia, otrzymały wsparcie z Międzynarodowego Funduszu Walutowego oraz Unii Europejskiej w ramach Europejskiego Mechanizmu Stabilizacji Finansowej (EFSM) oraz Europejskiego Instrumentu Stabilności Finansowej (EFSF), bez którego nie mogłyby poradzić sobie z rozwiązaniem problemów finansowych. Zawirowania fiskalne wskazały również ponownie na potrzebę wprowadzenia lub wzmocnienia obecnie już funkcjonujących odpowiednich ram zarządzania fiskalnego [Schick 2010; Fatas, Mihov 2003].

$\mathrm{Na}$ Węgrzech podstawową zasadą numeryczną, jaka obowiązuje, jest reguła długu publicznego obowiązująca w latach 1996-2011 na poziomie samorządu terytorialnego. W części tego okresu od 2009 r. obowiązuje już reguła długu w odniesieniu do sektora rządowego i ubezpieczeń społecznych. Reguła wymaga aktu budżetowe- 
go w celu określenia pierwotnego celu bilansowego na drugi rok następujący po roku przedmiotowym, tak aby: (a) pierwotny cel bilansowy nie był deficytem pierwotnym, (b) rzeczywisty dług publiczny nie wzrósł w roku następującym po ostatnim roku i (c) oczekiwany dług publiczny na koniec drugiego roku po tym, jak przedmiotowy rok nie może być wyższy niż dług pod koniec drugiego roku poprzedzającego przedmiotowy rok. Konieczne jest określenie zmiany w planowanych pierwotnych wydatkach rządowych pomiędzy pierwszym i drugim rokiem po roku przedmiotowym w ujęciu realnym [European Commission 2016]. Reguła ta w kolejnych latach była doprecyzowana, tak aby po zmianach w 2015 r. można było jednoznacznie stwierdzić, że dopóki dług publiczny przekracza połowę Produktu Krajowego Brutto, Zgromadzenie Narodowe może przyjąć jedynie taką ustawę budżetową, która zawiera redukcję długu publicznego proporcjonalnie do PKB.

$\mathrm{Na}$ Słowacji obowiązuje krajowa zasada równowagi całego sektora finansów publicznych, która stosunkowo niedawno została wprowadzona. Jednak zasada dyscyplinująca samorządy terytorialne w obrębie dopuszczalnego poziomu deficytu funkcjonuje już od 2002 r. W 2009 r. wprowadzono możliwość nakładania sankcji na gminy w przypadku niezgodności z wprowadzonymi zasadami. W tym samym czasie limit zadłużenia został nałożony na lokalny sektor rządowy (regionalny i lokalny). Limit ustalono na $60 \%$ nominalny dochód bieżący w roku poprzednim. Limit również był nałożony na roczne raty spłaty długów, które nie mogą przekraczać $25 \%$ nominalnego dochodu w poprzednim roku budżetowym. Wdrożenie zobowiązań wynikających z podpisania Paktu fiskalnego w 2012 r. doprowadziło do wprowadzenia nowej reguły dotyczącej długu, w zakresie której objęty został nią cały sektor finansów publicznych. Ta zasada została wprowadzona przez Ustawę konstytucyjną o odpowiedzialności fiskalnej. Rozwiązanie przypomina działanie procedur ostrożnościowych i naprawczych w Polsce od $1998 \mathrm{r}$. Na Słowacji wyznaczono cztery progi zadłużenia: 1) 50-53\% PKB; 2) 53-55\% PKB; 3) 55-57\% PKB; 4) $57-60 \%$ PKB [Moździerz 2015].

W Polsce mamy dwie podstawowe reguły, $\mathrm{tj}$. regułę długu publicznego i regułę wydatkową. Główną regułą fiskalną do 2013 r. była tzw. reguła zadłużenia, ujęta w dwóch aktach prawnych: Konstytucji RP oraz Ustawie z dnia 27 sierpnia 2009 r. o finansach publicznych (wprowadzona po raz pierwszy w ustawie z dnia 26 listopada 1998 r. o finansach publicznych). Reguła konstytucyjna określa limit państwowego długu publicznego, wskazując, że nie wolno zaciągać pożyczek lub udzielać gwarancji i poręczeń finansowych, w następstwie których państwowy dług publiczny przekroczy trzy piąte wartości rocznego PKB. Uzupełnieniem tej zasady jest reguła ustawowa wyznaczająca progi ostrożnościowe dotyczące państwowego długu publicznego, przez wprowadzenie progów państwowego długu publicznego w relacji do PKB na poziomie 43, 48 oraz $60 \%$ przekroczenie przepisów skutkuje wprowadzeniem procedur ostrożnościowych i sanacyjnych. Dopełnieniem reguł długu publicznego odnoszących się do całego sektora finansów publicznych są regulacje ustanowione $\mathrm{w}$ ustawie o finansach publicznych ograniczające poziom zadłużania 
się na poziomie lokalnym przez jednostki samorządu terytorialnego. Reguła długu publicznego dla JST ogranicza i uzależnia możliwość zadłużania się tych jednostek od poziomu dotychczasowego zadłużenia oraz możliwości jego obniżenia w kolejnych latach.

W Czechach w 2016 r. zostały stworzone nowe ramy zawierające następujące elementy: reguła wydatkowa mająca na celu ograniczenie wzrostu wydatków poprzez cyklicznie dostosowywane przychody i hamulec zadłużenia na poziomie zadłużenia odpowiadającym 55\% PKB w celu uniknięcia niezrównoważonych poziomów zadłużenia. Ponadto ten zestaw zasad jest uzupełniany przez Radę Budżetową. Czeska reguła długu publicznego jest uzupełniona kilkoma klauzulami wyjątków. Obowiązek przedłożenia nowej ustawy budżetowej i ograniczenia w finansach sektora publicznego nie mają zastosowania, gdy spełnione są następujące warunki: a) gospodarka doświadcza poważnego spowolnienia gospodarczego, które definiuje się jako dwuletni okres po spadku realnego PKB o 2\% w ciągu jednego kwartału lub o 3\% rocznie w stosunku do roku, b) kraj stoi w obliczu zagrożeń bezpieczeństwa lub znajduje się w stanie wojny lub c) rząd jest zmuszony reagować na klęski żywiołowe lub nakłady związane $\mathrm{z}$ wypełnianiem umów międzynarodowych, jeżeli przewiduje się, że koszty te będą wyższe niż 3\% szacowanego PKB [Baxa, Paulus 2016].

\section{Charakterystyka stanu finansów publicznych w krajach grupy Wyszehradzkiej}

Historia transformacji w krajach grupy V4 była bardzo podobna, jednak pomiędzy poszczególnymi krajami występowały pewne różnice dotyczące polityki gospodarczej, które rzutowały m.in. na tempo wzrostu gospodarczego (PKB), stan finansów publicznych czy poziom zamożności społeczeństwa. W zakresie oceny sytuacji sektora finansów publicznych odzwierciedlają stan reform gospodarczych, obowiązujących na poziomie krajowym regulacji prawnych i wymogów przyjętych przez władze publiczna w poszczególnych państwach V4.

Kraje te oprócz wspólnej historii i położenia geograficznego łączy jeszcze jedno: dzień przyjęcia do Unii Europejskiej - 1 maja 2004 r. Dzień ten był nie tylko milowym krokiem z punktu widzenia geopolitycznych zmian zachodzących w Europie, ale miał także istotny wpływ na prowadzenie polityki gospodarczej, w tym fiskalnej, przez kraje Grupy Wyszehradzkiej [Grauwe, Foresti 2015; Gadomski 2018]. Kraje te od tego momentu zobligowane były do inkorporacji i stosowania zapisów traktatowych odnośnie do koordynacji polityki gospodarczej państw członkowskich UE. Główne zapisy sformułowano w Pakcie na rzecz Stabilności i Wzrostu (PSiW). Regulacje w nim uchwalone przez Komisję Europejską były impulsem dla krajów z Grupy Wyszehradzkiej do wzmocnienia skuteczności funkcjonujących reguł i innych instrumentów fiskalnych [Buti, Giudice 2002]. Każdego roku w kwietniu państwa strefy euro przedkładają przed Komisją i Radą programy stabilności, a kraje nienależące do strefy euro programy konwergencji [Dyrektywa Rady 2011/85/UE]. 
Tabela 1. Stan finansów publicznych w krajach V4 w latach 2005-2016

\begin{tabular}{|c|c|c|c|c|c|c|c|c|c|c|c|c|}
\hline Lata & 2005 & 2006 & 2007 & 2008 & 2009 & 2010 & 2011 & 2012 & 2013 & 2014 & 2015 & 2016 \\
\hline \multicolumn{13}{|c|}{ Czechy } \\
\hline Dług publiczny $\%$ PKB & 27,9 & 27,7 & 27,5 & 28,3 & 33,6 & 37,4 & 39,8 & 44,5 & 44,9 & 42,2 & 40 & 36,8 \\
\hline Deficyt w \% PKB & -3 & $-2,2$ & $-0,7$ & -2 & $-5,5$ & $-4,2$ & $-2,7$ & $-3,9$ & $-1,2$ & $-1,9$ & $-0,6$ & 0,7 \\
\hline \multicolumn{13}{|c|}{ Polska } \\
\hline Dług & 46,4 & 46,9 & 44,2 & 46,3 & 49,4 & 53,1 & 54,1 & 53,7 & 55,7 & 50,2 & 51,1 & 54,1 \\
\hline Deficyt w \% PKB & -4 & $-3,6$ & $-1,9$ & $-3,6$ & $-7,3$ & $-7,3$ & $-4,8$ & $-3,7$ & $-4,1$ & $-3,6$ & $-2,6$ & $-2,5$ \\
\hline \multicolumn{13}{|c|}{ Słowacja } \\
\hline Dług publiczny $\%$ PKB & 34,1 & 31 & 30,1 & 28,5 & 36,3 & 41,2 & 43,7 & 52,2 & 54,7 & 53,5 & 52,3 & 51,8 \\
\hline $\mathrm{w} \%$ PKB & $-2,9$ & $-3,6$ & $-1,9$ & $-2,4$ & $-7,8$ & $-7,5$ & $-4,3$ & $-4,3$ & $-2,7$ & $-2,7$ & $-2,7$ & $-2,2$ \\
\hline \multicolumn{13}{|c|}{ Węgry } \\
\hline Dług & 60 & 64,1 & 65 & 71 & 77,2 & \begin{tabular}{|l|}
79,7 \\
\end{tabular} & 79,9 & 77,6 & 76 & 75,2 & 74,7 & 73,9 \\
\hline Deficyt w \% PKB & $-7,8$ & $-9,3$ & -5 & $-3,7$ & $-4,5$ & $-4,5$ & $-5,4$ & $-2,4$ & $-2,6$ & $-2,7$ & -2 & $-1,9$ \\
\hline
\end{tabular}

Źródło: opracowanie własne na podstawie danych Eurostatu.

12-letni okres członkostwa krajów Grupy Wyszehradzkiej jest już dobrą podstawą do oceny, czy udało się im wywiązywać z regulacji unijnych w zakresie prowadzenia polityki gospodarczej zgodnej ze sformułowanymi zasadami fiskalnymi.

Przystąpienie do strefy euro tylko Słowacji skłania do refleksji, czy pozostałe kraje Grupy Wyszehradzkiej nie przystąpiły do strefy euro, kierując się przesłankami politycznymi, czy też w sposób niewystarczający dostosowały politykę fiskalną, aby spełnić kryteria z Maastricht. Analiza ocen dokonanych przez Komisję Europejską wskazuje na tę drugą przyczynę.

W analizowanym okresie 2005-2016 wszystkie badane państwa były przynajmniej raz objęte przez Komisję Europejską procedurą nadmiernego deficytu [European Commission 2016].

Podsumowując: w analizowanym okresie kraje Grupy Wyszehradzkiej pomimo nakładanych procedur nadmiernego deficytu starały się dość skutecznie spełnić kryteria integracji gospodarczej określonej w Traktacie (por. tab. 1). Zdecydowanie większy problem był ze spełnieniem kryterium deficytu niż długu publicznego. W kontekście tego pojawiło się ważne pytanie badawcze: czy stosowane przez kraje Grupy Wyszehradzkiej instrumenty finansowe i reguły fiskalne mają wpływ na taką sytuację oraz czy działania KE w tym zakresie mogą w przyszłości przynieść oczekiwane rezultaty.

\section{Wnioski i rekomendacje ze stosowania reguł długu publicznego w krajach V4}

Przeprowadzone badania na krajach Grupy Wyszehradzkiej dokonane zostały w aspekcie wpływu indeksu reguł fiskalnych nie tylko na stan finansów publicznych. W pierwszej kolejności wykonana została analiza korelacji $r$ Pearsona. Jest to para- 
metryczna metoda badająca związek między dwoma zmiennymi mierzonymi na skali ilościowej. Wyniki istotne statystycznie oznaczają występowanie związku między zmiennymi. Związki między zmiennymi mogą być dodatnie (wzrost jednej zmiennej powiązany jest ze wzrostem drugiej zmiennej) lub ujemne (wzrost jednej zmiennej powiązany jest ze spadkiem drugiej zmiennej) (tab. 2). Dokonano analizy wpływu stosowanych reguł fiskalnych wyrażonych Standardised fiscal rules index ${ }^{1}$ przez kraje Grupy Wyszehradzkiej na ich deficyt i dług publiczny.

Tabela 2. Wyniki analizy korelacji dla wybranych wskaźników finansów publicznych

\begin{tabular}{|l|c|c|c|c|}
\hline \multirow{2}{*}{ Wyszczególnienie } & \multicolumn{4}{c|}{ Standardised fiscal rules index } \\
\cline { 2 - 5 } & Czechy & Węgry & Polska & Słowacja \\
\hline Wzrost Produktu Krajowego Brutto & $0,71^{* *}$ & 0,26 & 0,33 & $0,88^{* * *}$ \\
\hline Deficyt sektora finansów publicznych w \% PKB & 0,52 & $0,61^{*}$ & $0,58^{*}$ & 0,40 \\
\hline Deficyt sektora rządowego w \% PKB & 0,51 & $0,59^{*}$ & $0,64^{*}$ & 0,38 \\
\hline Deficyt sektora samorządowego w \% PKB & $0,72^{* *}$ & 0,22 & 0,55 & $0,63^{*}$ \\
\hline
\end{tabular}

$$
{ }^{*} p<0,05 ;{ }^{* *} p<0,01 ;{ }^{* * *} p<0,001 \text {. }
$$

Źródło: opracowanie własne.

Analiza korelacji $r$ Pearsona dla Czech i Słowacji wykazała, że była istotna statystycznie i dodatnia korelacja między Standardised fiscal rules index a wzrostem relacji poziomu długu publicznego do PKB (GDP) $r=0,71, p<0,01$ oraz $r=0,88$, $p<0,001$. Jeśli zaś chodzi o kwestie związane z poziomem deficytu całego sektora finansów publicznych, to były one statystycznie dodatnio skorelowane ze Standardised fiscal rules index w przypadku Węgier i Polski. Wyniki tych badań jednoznacznie potwierdzają, że zdefiniowany przez Komisję Europejską Standardised fiscal rules index nie ma bezpośredniego przełożenia pozytywnego na stan finansów publicznych badanych krajów. Istnieć może kilka powodów takiego wyniku. Pierwszy $\mathrm{z}$ nich to to, że wdrożenie reguł nie oznacza automatycznego przynoszenia przez nich efektu w konkretnym, tym samym roku. Ponadto w analizowanym okresie zaburzenie wyników było spowodowane kryzysem 2007/2008 r., który miał konsekwencje dla całej sfery finansów oraz realnej gospodarki. W tym okresie od niepamiętnych czasów wdrażano niekonwencjonalne pakiety konsolidujące, wspierające

${ }^{1}$ Standardised fiscal rules index (indeks reguł fiskalnych) jest stworzony i monitorowany przez Komisję Europejską. Indeks ten jest stworzony na bazie informacji dotyczących zaawansowania we wdrożeniu reguł fiskalnych w danym kraju UE. Podstawą jego obliczenia jest wskaźnik siły reguły fiskalnej (FRSI), biorący pod uwagę pięć podstawowych kryteriów: (1) ustawową podstawę reguły, (2) przestrzeń do zmiany celów, (3) monitorowanie przestrzegania i egzekwowania przepisów, (4) istnienie $\mathrm{z}$ góry określonego wykonania mechanizmów i (5) widoczność medialną reguły. Tę metodologię zainspirowali w 2006 r. S. Deroose, L. Moulin i P. Wierts. Dla powyższych kryteriów, dla każdej reguły wyniki są przypisywane w następujący sposób: złożony wskaźnik Fiscal Rule Strength oblicza się dla każdej reguły, agregując powyższe wyniki. 
chociażby sektor bankowy. Zdecydowano się w związku z tym na dokonanie głębszej analizy, tzn. przeprowadzono badanie wpływu europejskiego indeksu reguł fiskalnych na grupy współczynników z uwzględnieniem zmiany w czasie.

Ze względu na to, że duża liczba zmiennych notowała stałe trendy w analizowanym czasie, wykonana została jeszcze raz analogiczna analiza regresji jak w problemie badawczym $\mathrm{nr} 2 \mathrm{z}$ uwzględnieniem czasu. Niestety dokonane analizy nie wykazały zmienności w czasie poza przypadkiem Polski. Dla Polski bowiem analizy wykazały, że przy braku zmienności w czasie Standardised fiscal rules index okazał się istotnie, dodatnio i silnie wpływać na inwestycje, wydatki publiczne w szczególności na obsługę długu i bieżącą działalność, skalę wydatków publicznych w relacji do PKB, deficyt w relacji do PKB oraz zdolność nabywczą ludności. Standardised fiscal rules index miał najsilniejszy dodatni wpływ w Polsce na deficyt sektora finansów publicznych w relacji do PKB.W takiej sytuacji zdecydowano się na wprowadzenie jeszcze jednego dodatkowego czynnika, tzn. dokonano badania wpływu indeksu reguł fiskalnych na długoterminowe oprocentowanie papierów wartościowych w krajach Grupy Wyszehradzkiej (tab. 3).

Tabela 3. Wyniki analizy korelacji dla oprocentowania krajowych papierów wartościowych

\begin{tabular}{|c|c|c|c|c|}
\hline \multirow{2}{*}{ Wyszczególnienie } & \multicolumn{4}{|c|}{ Standardised fiscal rules index } \\
\cline { 2 - 5 } & Czechy & Węgry & Polska & Słowacja \\
\hline Rentowność 10-letnich bonów skarbowych & $-0,89^{* * * *}$ & $-0,70^{*}$ & $-0,50$ & $-0,93^{* * *}$ \\
\hline
\end{tabular}

${ }^{*} p<0,05 ;{ }^{* *} p<0,01 ;{ }^{* * *} p<0,001$.

Źródło: opracowanie własne.

Uzyskane wyniki wskazują zależności, ich skala jest jednak różna i wprost zależy od rodzaju reguł fiskalnych stosowanych przez dane kraje. Udało się uzyskać w przeprowadzonych badaniach jedną zależność wspólną dla wszystkich krajów, a mianowicie odwrotną korelację między stopą oprocentowania długoterminowych papierów wartościowych a wzrostem Standardised fiscal rules index.

\section{Zakończenie}

W ocenie skuteczności reguł fiskalnych uwagę należy skupić na ich konstrukcji oraz dopasowaniu do realizowanych celów społeczno-gospodarczych. Wyżej wymienione warunki wbrew pozorom nie są łatwe do spełnienia. Proste kotwice fiskalne, np. limitowane tempo wzrostu wydatków publicznych czy też limitowany poziom deficytu, nie mają uniwersalnego zastosowania i mogą zostać użyte w specyficznych warunkach. Wokół przejściowych rozwiązań nie daje się zbudować odpowiedniego systemu nadającego kotwicy wysoką wiarygodność. Z kolei bardziej złożone kotwice limitujące, np. poziom dopuszczalnego deficytu strukturalnego, wymagają odpo- 
wiednich obliczeń. Otwiera to możliwość dokonywania arbitralnych szacunków, np. produkcji potencjalnej, tym samym pozwala na naginanie kotwicy do bieżącej sytuacji politycznej. Warunek dotyczący mechanizmu sanacji finansów publicznych musi być wykonalny, a przez to wiarygodny. Przeprowadzenie tego rodzaju projekcji przy wykorzystaniu budżetu zadaniowego daje odpowiedź na pytanie, czy funkcje państwa są wykonywane i w jakiej skali. Przebieg ograniczenia deficytu fiskalnego musi być odpowiednio zaprojektowany. W tym zakresie powstaje istotny problem, czy reguła budżetowa powinna dotyczyć deficytu, czy też wysokości długu publicznego. Z punktu widzenia rynków finansowych kluczowy wydaje się odpowiedni poziom długu. $Z$ jednej strony rynki finansowe, znając strukturę długu i przewidywany deficyt, są w stanie określić skalę potrzeb pożyczkowych. Z drugiej strony, mając na uwadze ocenę zdolności danego kraju do przeprowadzenia manewru konsolidacji budżetowej, rynki określają dopuszczalny poziom długu, który w ich opinii dany kraj jest w stanie długoterminowo finansować. Dopuszczalny poziom długu nie oznacza bezpiecznego poziomu zadłużenia. Zawirowania na rynkach finansowych i związane z tym zmiany w wycenie ryzyka mogą czasowo zmniejszać zakres dostępu do rynków finansowych dla poszczególnych krajów. Bezpieczny poziom długu powinien być ustalony na niższym poziomie od dopuszczalnego. Przeprowadzone badania wykazały, że w przypadku krajów Grupy Wyszehradzkiej oparto się właśnie na tych założeniach i osiągnięto oczekiwane rezultaty mierzone kosztem pozyskania środków z rynku finansowego.

\section{Literatura}

Alińska A., 2017, Implementacja i przestrzeganie regut fiskalnych $w$ wybranych państwach Europy Środkowo-Wschodniej, Studia Prawno-Ekonomiczne, t. 103, s. 173-191.

Baxa J., Paulus M., 2016, New fiscal rules for the Czech Republic: Analysis of the proposal, IES Occasional Paper, no. 1/2016.

Bova E., Carcenac N., Guerguil M., 2014, Fiscal rules and the procyclicality of fiscal policy in the developing world, IMF Working Paper, no. 14/122.

Bova E., Kinda T., Muthoora P., Toscani F., 2015, Fiscal Rules at Glance, International Monetary Fund, Wasington, DC.

Buti M., Giudice G., 2002, Maastricht's Fiscal Rules at Ten: An Assessment, Journal of Common Market Studies, vol. 40, no. 5, s. 823-848, https://onlinelibrary.wiley.com/doi/abs/10.1111/1468-5965. 00399.

Dyrektywa Rady 2011/85/UE z dnia 8 listopada 2011 r. w sprawie wymogów dla ram budżetowych państw członkowskich, Dziennik Urzędowy Unii Europejskiej L 306 z dnia 23 listopada 2011 r.

European Commission, 2016, Fiscal Rules Database, http://ec.europa.eu/economy_finance/db_indicators/fiscal_governance/fiscal_rules/index_en.htm (5.11.2016).

Fatas A., Mihov I., 2003, On constraining fiscal policy discretion in EMU, Oxford Review of Economic Policy, vol. 19, no. 1, s. 112-131.

Gadomski W., 2018, Kraje Wyszehradzkie bliższe politycznie niż gospodarczo, https://www.obserwatorfinansowy.pl/tematyka/makroekonomia/kraje-wyszehradzkie-blizsze-politycznie-nizgospodarczo/. 
Grauwe P. de, Foresti P., 2015, Fiscal rules, financial stability and optimal currency areas, CESIFO Working Paper, no. 5390.

MFW, 1999, Code of Good Practices on Fiscal Transparency, IMF Manual on Monetary and Financial Transparency, www.imf.org/external/np/fad/manual.html.

Moździerz A., 2015, Strengthening the post-crisis fiscal rules - the case of Spain, Slovakia and Sweden, EQUILIBRIUM. Quarterly Journal of Economics and Economic Policy, vol. 10, no. 2, s. 31-52.

Musgrave R.A., Musgrave P.B., 1984, Public Finance in Theory and Practice, McGraw-Hill, New York.

OECD, 2016, The State of Public Finances 2015: Strategies for Budgetary Consolidation and Reform in OECD Countries, OECD Publishing, Paris, http://www.oecd.org/governance/the-state-of-public-finances-2015-9789264244290-en.htm.

Postuła M., 2017, Finanse publiczne w architekturze wspótczesnej gospodarki. Teoria a polska praktyka gospodarcza, Difin, Warszawa.

Poterba J.M., 1994, State responses to fiscal crisis: The effects of budgetary institutions and politics, Journal of Political Economy, vol. 102.

Schick A., 2010, Post-crisis fiscal rules: Stabilising public finance while responding to economic aftershocks, OECD Journal on Budgeting, vol. 2010/2. 